\title{
AKTIVITAS MUSYAWARAH GURU MATA PELAJARAN (MGMP) ILMU PENGETAHUAN SOSIAL (IPS) DALAM PENGEMBANGAN PROFESI GURU BERKELANJUTAN (MTSN JAKTIM)
}

\author{
Isma Nurfitri, Zaharah \\ ismaanf13@mhs.uinjkt.ac.id \\ zaharah@uinjkt.ac.id \\ (Fakultas Ilmu Tarbiyah dan Keguruan (FITK) UIN Syarif Hidayatullah Jakarta)
}

\begin{abstract}
Abstrak:
Aktivitas Musyawarah Guru Mata Pelajaran (MGMP) khususnya IPS dalam pengembangan profesi guru berkelanjutan adalah suatu forum atau wadah kegiatan professional guru mata pelajaran sejenis di masing-masing sekolah yang terdiri dari dua unsur yaitu musyawarah dan guru mata pelajaran tujuanya memberikan sosialisasi kurikulum yang sedang berlaku dan gambaran serta pemahaman tentang silabus yang berlaku, pembelakalan dan solusi tentang permasalahan pembelajaran, pembekalan bagi guru mata pelajaran dalam menentukan Kriteria Ketuntasan Minimal dan pembekalan bagi penyusunan Rencana Pelaksanaan Pembelajaran
\end{abstract}

Kata kunci: Aktivitas, Berkelanjutan, Guru, MGMP.

\section{A. Pendahuluan}

Dalam sekolah, proses pendidikan berlangsung dengan tujuan membekali peserta didik agar menjadi manusia yang bermartabat dan siap dalam menghadapi tantangan di masa yang akan datang, serta dapat bertanggung jawab atas dirinya sendiri dalam hidup bermasyarakat. Proses pendidikan di sekolah dilakukan melalui kegiatan belajar mengajar. Selanjutnya keberhasilan kegiatan belajar mengajar akan mengantarkan peserta didik pada tujuan yang hendak dicapai. salah satu faktor terpenting dalam keberhasilan kegiatan belajar mengajar adalah figur seorang guru yang dengan kemampuan dan kompetensi yang dimiliki mampu mendidik dan mengajar dengan baik. Guru merupakan seseorang yang mengambil peran sangat penting dalam proses kegiatan belajar mengajar karena ia terlibat secara langsung dengan peserta didik dan menjadi orang pertama yang mengetahui perkembangan dari peserta didik itu sendiri.

Guru adalah jabatan professional yang memerlukan berbagai keahlian khusus. Sebagai suatu profesi, maka harus memenuhi kriteria profesional. Ada banyak tanggung jawab guru dalam menjalankan tugas profesi diiringi dengan sejumlah kompetensi dan kemampuan yang harus dimiliki oleh seorang guru dalam menunjang profesinya tersebut. Berhubungan dengan kompetensi, Undang-Undang Nomor 14 Tahun 2005 tentang guru dan dosen menyebutkan kompetensi adalah seperangkat pengetahuan, keterampilan dan perilaku yang harus dimiliki, dihayati, dan dikuasai oleh guru atau dosen dalam melaksanakan tugas keprofesionalan. ${ }^{1} \quad$ Kompetensi tersebut adalah yang tertera dalam Pasal

\footnotetext{
${ }^{1}$ Undang-undang No. 14 tahun 2005 Tentang Guru Dan Dosen
} 
10 Undang-Undang Nomor 14 Tahun 2005 tentang guru dan dosen yaitu "kompetensi guru yang dimaksud meliputi kompetensi pedagogik, kompetensi kepribadian, kompetensi sosial, dan kompetensi professional yang diperoleh melalui pendidikan profesi. ${ }^{2}$

Guru dapat dikatakan profesional jika telah memiliki empat kompetensi ini. Namun pada kenyataannya, di Indonesia masih banyak tenaga pendidik atau guru yang belum memenuhi standar dari kompetensi yang dibutuhkan untuk menjadi tenaga pendidik yang professional, sehingga dapat dikatakan kualitas guru di Indonesia masih rendah. Potret rendahnya kualitas guru di Indonesia terlihat dari hasil Uji Kompetensi Guru (UKG) di tahun 2015, yang menunjukkan bahwa dari 1,6 juta guru yang mengikuti UKG, hanya 192 guru saja yang memperoleh nilai di atas 90,00. Sementara nilai rata-rata guru keseluruhan hanya 53,05. Nilai rerata yang dicapai peserta UKG tersebut masih berada di bawah standar kompetensi minimal yang ditetapkan Kemendikbud, yakni 55,00 (dari rentang nilai 10,00 s.d 100,00).

Pemerintah berupaya untuk meningkatkan kompetensi guru melalui pembinaan serta sederet program lainnya agar guru atau tenaga pendidik dapat mencapai kompetensi yang diharapkan, sehingga ke depannya pendidikan di Indonesia akan jauh lebih baik di tangan guru-guru yang memiliki kualifikasi dan standar yang tinggi. Peningkatan kompetensi pada guru merupakan suatu kewajiban yang harus dilaksanakan dalam

${ }^{2}$ Pasal 10 Ayat 1 Undang-undang no. 14 Thn 2005 Tentang Guru Dan Dosen melaksanakan tugas keprofesionalannya, yang juga tertulis dalam Undang-Undang tentang Guru dan Dosen Pasal 20 butir b dalam, yaitu meningkatkan dan mengembangkan kualifikasi akademik dan kompetensi secara berkelanjutan sejalan dengan perkembangan ilmu pengetahuan, teknologi, dan seni. Bentuk dari pengembangan profesi berkelanjutan itu bisa dilakukan dari inisiatif gurunya sendiri dalam mengembangkan kompetensinya dengan berbagai cara. Sebaliknya pengembangan professional berkelanjutan dapat juga dilakukan secara institusional atas inisiatif dari kepala sekolah, atau otoritas pendidikan terkait, misalnya melalui perkumpulan dalam wadah-wadah guru seperti Musyawarah Guru Mata Pelajaran (MGMP). Jadi melalui forum atau wadah tersebut, guru dapat berbagi pengalaman seputar masalah dalam pembelajaran, mencari solusinya serta mengevaluasi hasil kinerjanya.

Seperti diketahui bahwa MGMP merupakan organisasi yang ada di setiap tingkat kabupaten atau kota, salah satunya ada juga MGMP IPS tingkat Madrasah Tsanawiyah (MTs) atau setara dengan Sekolah Menengah Pertama (SMP) yang berada di Jakarta Timur. Dari 5 wilayah administratif DKI Jakarta, MGMP IPS MTs di wilayah Jakarta Timur merupakan yang paling aktif dalam mengadakan pertemuan maupun sejumlah kegiatan. Hal ini juga dikarenakan jumlah MTs Negeri yang terdapat di Jakarta Timur paling banyak dibandingkan wilayah yang lain, yaitu terdapat 18 MTs Negeri. MGMP tersebut menaungi seluruh guru IPS yang mengajar di MTs Negeri wilayah Jakarta Timur. Maka dari itu, kegiatan MGMP IPS MTs Jakarta Timur yang aktif 
membuat peneliti tertarik untuk melakukan penelitian dengan tujuan mencari tahu tentang aktivitas apa saja yang ada di dalam organisasi MGMP terkait dengan pengembangan profesi guru berkelanjutan, khususnya MGMP IPS tingkat MTs.

\section{B. Kajian Teori}

\section{Pengertian MGMP}

MGMP (Musyawarah Guru Mata Pelajaran) adalah forum/wadah kegiatan professional guru mata pelajaran pada SMP/MTs, SMPLB/MTsLB, SMA/MA, SMK/MAK, SMALB/MALB yang berada pada satu wilayah/kabupaten/kota/ kecamatan/sanggar/gugus sekolah. ${ }^{3}$ MGMP adalah suatu forum atau wadah kegiatan professional guru mata pelajaran sejenis di sanggar maupun di masingmasing sekolah yang terdiri dari dua unsur yaitu musyawarah dan guru mata pelajaran. ${ }^{4}$

Dari penjelasan di atas dapat disimpulkan bahwa MGMP merupakan suatu forum yang berupaya dalam mengembangkan kompetensi bagi tiap-tiap guru mata pelajaran agar kualitasnya semakin meningkat. Di mana MGMP mewadahi guru-guru mata pelajaran untuk berkumpul dan saling berbagi pengalaman dalam hal mengajar sehingga guru-guru dapat bertukar pikiran. Ini merupakan suatu hal positif karena melalui MGMP ini guru yang memiliki kendala dan kesulitan dalam prosesnya mengajar di kelas bisa

${ }^{3}$ Direktorat Profesi Pendidik, Standar Pengembangan: Kelompok Kerja Guru (KKG) Musyawarah Guru Mata pelajaran (MGMP), (Jakarta: Departemen Pendidikan Nasional, 2008), h. 6 .

${ }^{4}$ Ramayulis, Profesi \& Etika Keguruan. (Jakarta: Kalam Mulia, 2013), h. 487. dicarikan solusinya. Sejumlah kegiatan dan pelatihan yang tentunya tersusun dan terprogram di organisasi ini memang sudah dirancang dengan tujuan membantu para guru yang mengalami kesulitan dalam proses mengajar. Jadi, diharapkan setiap guru yang mengikuti kegiatan MGMP ini semakin lama kualitas dan kompetensinya akan terus meningkat.

\section{Tujuan MGMP}

Dalam Standar Pengembangan Kelompok Kerja Guru (KKG) Musyawarah Guru Mata Pelajaran (MGMP) Direktorat Jenderal Peningkatan Mutu Pendidik dan Tenaga Kependidikan Departemen Pendidikan Nasional Republik Indonesia tahun 2008 menyebutkan beberapa tujuan dari pelaksanaan MGMP, yaitu:

a. Memperluas wawasan dan pengetahuan guru dalam berbagai hal, khususnya penguasaan substansi materi pembelajaran, penyusunan silabus, penyusunan bahan-bahan pembelajaran, strategi pembelajaran, metode pembelajaran, memaksimalkan pemakaian sarana/prasarana belajar, memanfaatkan sumber belajar.

b. Memberi kesempatan kepada anggota kelompok kerja atau musyawarah kerja untuk berbagai pengalaman serta saling memberikan bantuan dan umpan balik.

c. Meningkatkan pengetahuan dan keterampilan, serta mengadopsi pendekatan pembaharuan dalam pembelajaran yang lebih professional bagi peserta kelompok kerja atau musyawarah.

d. Memberdayakan dan membantu anggota kelompok kerja dalam 
melaksanakan

tugas-tugas

pembelajaran di sekolah.

e. Mengubah budaya kerja anggota kelompok kerja atau musyawarah kerja (meningkatkan pengetahuan, kompetensi dan kinerja) dan mengembangkan profesionalisme guru melalui kegiatan-kegiatan pengembangan professionalism di tingkat KKG/MGMP.

f. Meningkatkan mutu proses pendidikan dan pembelajaran yang tercermin dari peningkatan hasil belajar peserta didik.

g. Meningkatkan kompetensi guru melalui kegiatan-kegiatan di tingkat KKG/MGMP. ${ }^{5}$

\section{Peran MGMP}

Jika dilihat dari beberapa tujuan yang telah dijelaskan di atas, MGMP memiliki peran yakni sebagai berikut:

a. Sarana guru mata pelajaran dalam memperluas wawasan dan pengetahuan guna mewujudkan proses pembelajaran yang efektif, efisien, menyenangkan dan mencerdaskan.

b. Turut berperan dalam membangun kerja sama dengan masyarakat sebagai mitra guru dalam melaksanakan proses pembelajaran.

c. MGMP diharapkan dapat menyelesaikan permasalahanpermasalahan yang dihadapi guru baik itu dalam hal karakteristik mata pelajaran, kondisi lingkungan sekolah, pelaksanaan kurikulu, metodologi serta penyesuaian terhadap perkembangan ilmu pengetahuan dan teknologi.

d. Berperan dalam meningkatkan dan menyetarakan kemampuan guru dalam mempersiapkan, melaksanakan, dan

${ }^{5}$ Direktorat Profesi Pendidik, op. cit., h. 4-5. mengevaluasi program kegiatan belajar mengajar. ${ }^{6}$

\section{Standar Pengembangan MGMP}

Dalam pedoman pengembangan MGMP, terdapat beberapa standar dalam pengembangan MGMP, diantaranya:
a. Standar Program
b. Standar Organisasi
c. Standar Pengelolan
d. Standar Sarana dan Prasarana
e. Standar Sumber Daya Manusia
f. Standar Pembiayaan
g. Standar Penjaminan $\mathrm{Mutu}^{7}$

\section{Ilmu Pengetahuan Sosial (IPS) \\ 1. Pengertian IPS}

Ilmu Pengetahuan Sosial (IPS) merupakan integrasi dari berbagai cabang ilmu-ilmu sosial, seperti sosiologi, sejarah, geografi, ekonomi, politik, hukum, dan budaya. Ilmu Pengetahuan Sosial dirumuskan atas dasar realitas dan fenomena sosial yang mewujudkan suatu pendekatan interdisipliner dari aspek dan cabang ilmu-ilmu sosial. ${ }^{8}$ Mata pelajaran ini berperan memfungsionalkan dan merealisasikan ilmu-ilmu sosial yang bersifat teoritik ke dalam dunia kehidupan nyata di masyarakat. ${ }^{9}$ Sesuai dengan

\footnotetext{
${ }^{6}$ Ahmad Juanda, "Kendala Musyawarah Guru Mata Pelajaran (MGMP) IPS dalam Mengembangkan Kompetensi Profesional dan Pedagogi Guru IPS SMP di Kabupaten Sleman Tahun 2013/2014", Skripsi pada Universitas Negeri Yogyakarta, Yogyakarta, 2015, h. 13-14, tidak dipublikasikan.

${ }^{7}$ Direktorat Profesi Pendidik, op. cit., h. 7-10.

${ }^{8}$ Trianto, Model Pembelajaran Terpadu: Konsep, Strategi, dan Implementasinya dalam Kurikulum Tingkat Satuan Pendidikan (KTSP), (Jakarta: PT BUmi Aksara, 2010), h. 171.

${ }^{9}$ Sapriya, dkk. Pembelajaran dan Evaluasi Hasil Belajar IPS, (Bandung: UPI Press, 2006), h. 3.
} 
pernyataan tersebut, materi yang ada pada mata pelajaran IPS berisi tentang teoriteori yang berkaitan dengan ilmu sosial dan kehidupan manusia yang kemudian dapat direalisasikan dalam kehidupan yang sebenarnya.

\section{Karakteristik Pembelajaran IPS}

Sapriya mengutip pandangan A. Kosasih Djahiri tentang ciri dan sifat utama atau karakteristik dari pembelajaran IPS, yaitu:

a. IPS berusaha mempertautkan teori ilmu dengan fakta atau sebaliknya (menelaah fakta dari segi ilmu).

b. Penelaahan dan pembahasan IPS tidak hanya dari satu bidang disiplin ilmu saja, melainkan bersifat komprehensif.

c. Mengutamakan peran aktif siswa melalui proses belajar inquiri agar siswa mampu mengembangkan berpikir kritis, rasional dan analitis.

d. Program pembelajaran disusun dengan meningkatkan/menghubungkan bahanbahan dari berbagai disiplin ilmu sosial lainnya dengan kehidupan nyata di masyarakat, pengalaman, permasalahan, kebutuhan dan memproyeksikannya kepada kehidupan di masa depan baik dari lingkungan fisik/alam maupun budayanya.

e. IPS dihadapkan secara konsep dan kehidupan sosial yang sangat labil (mudah berubah), sehingga titik berat pembelajaran adalah terjadinya proses internalisasi secara mantap dan aktif pada diri siswa agar siswa memiliki kebiasaan dan kemahiran untuk menelaah permasalahan kehidupan nyata pada masyarakatnya. f. IPS mengutamakan hal-hal, arti dan penghayatan hubungan antarmanusia yang bersifat manusiawi.

g. Pembelajaran tidak hanya menguataman pengetahuan semata, juga nilai dan keterampilannya.

h. Berusaha untuk memuaskan setiap siswa yang berbeda melalui program maupun pembelajarannya dalam arti memperhatikan minat siswa dan masalah-masalah kemasyarakatan yang dekat dengan kehidupannya.

i. Dalam pengembangan Program Pembelajaran senantiasa melaksanakan prinsip-prinsip karakteristik (sifat dasar) dan pendekatan-pendekatan yang menjadi ciri IPS itu sendiri. ${ }^{10}$

Dari karakteristik di atas dapat disimpulkan bahwa karakteristik Ilmu Pengetahuan Sosial (IPS) merupakan suatu pengintegrasian dari ilmu-ilmu sosial yang membahas seputar fakta dan berkaitan dengan manusia. Karena ilmu sosial membahas kehidupan manusia, dan kehidupan manusia merupakan suatu hal yang dinamis, maka pembelajaran IPS sendiri selalu diseimbangkan dan disesuaikan dengan perubahan zaman yang ada. Maka dari itu itu pembelajaran IPS cenderung kontekstual daripada tekstual.

\section{Fungsi dan Tujuan Pembelajaran IPS}

Menurut Nu'man Somantri yang dikutip oleh Sapriya, bahwa ada empat pendapat mengenai tujuan pembelajaran IPS di tingkat persekolahan, yaitu:

1) Untuk mendidik para siswa menjadi ahli ekonomi, hukum, sosiologi dan pengetahuan sosial lainnya.

\footnotetext{
${ }^{10}$ Ibid., h. 8 .
} 
2) Untuk menumbuhkan warga negara yang baik. Sifat warga negara yang baik akan mudah ditumbuhkan pada siswa apabila guru mendidik mereka dengan jalan menempatkannya dalam konteks kebudayaannya daripada memusatkan perhatian pada disiplin ilmu yang terpisah-pisah seperti dilakukan di universitas.

3) Bahan pembelajaran IPS harus dapat menampung para siswa untuk studi lanjutan ke universitas maupun yang akan terjun langsung pada kehidupan masyarakat. Sehingga tujuan pembelajaran IPS merupakan "simplikasi dan distilasi dari berbagai ilmu sosial untuk kepentingan pendidikan.

4) Untuk mempelajari bahan pelajaran yang sifatnya tertutup. Maksudnya yang tabu untuk dibicarakan, para siswa akan dapat memperoleh kesempatan untuk memecahkan konflik intrapersonal maupun antarpersonal. Bahan tabu tersebut yang timbul dari bidang ekonomi, politik, sejarah, sosiologi maupun ilmu-ilmu sosial lainnya. ${ }^{11}$

Fungsi dan tujuan pembelajaran IPS yang dimaksudkan di atas secara garis besarnya yaitu untuk membekali para siswa agar siap dalam menghadapi tantangan apapun setelah lulus nanti. Karena pembelajaran IPS juga mempelajari cara manusia berhubungan dengan manusia lainnya dan membangun masyarakat sesuai dengan hakikat berkehidupan berbangsa dan bernegara. Selain itu membekali siswa yang berminat untuk melanjutkan studinya tentang ilmu sosial ke tingkat yang lebih tinggi lagi.

\footnotetext{
${ }^{11}$ Sapriya dkk, op. cit., h. 11-12.
}

\section{Pengembangan Profesi Berkelanjutan 1. Pengertian Profesi}

Menurut Kamus Besar Bahasa Indonesia (KBBI) profesi adalah "bidang pekerjaan yang dilandasi pendidikan keahlian (keterampilan, kejuruan dan sebagainya) tertentu". ${ }^{12}$ Lalu menurut Sikun Pribadi yang dikutip oleh Oemar Hamalik bahwa "profesi itu pada hakikatnya adalah suatu pernyataan atau suatu janji terbuka, bahwa seseorang akan mengabdikan dirinya kepada suatu jabatan atau pekerjaan dalam arti biasa, karena orang tersebut merasa terpanggil menjabat pekerjaan itu". 13

Dari penjelasan mengenai profesi di atas, dapat disimpulkan bahwa profesi adalah suatu pekerjaan yang dapat dilakukan seseorang hanya dengan keterampilan khusus dan keahlian yang bisa didapatkan dari pendidikan dalam jangka waktu yang cukup lama serta memiliki serangkaian aturan yang biasa disebut kode etik. Pada hakikatnya seseorang memutuskan untuk memilih pekerjaan atau profesi yang akan diembannya didasari atas keinginan untuk mengabdikan diri sepenuhnya pada pekerjaan atau profesinya tersebut.

\section{Ciri-Ciri Profesi}

Menurut Rochman Natawidjaja yang dikutip oleh Syafruddin Nurdin, mengemukakan beberapa kriteria sebagai ciri suatu profesi, yaitu:

a. Ada standar untuk kerja yang baku dan jelas.

\footnotetext{
${ }^{12}$ Syafruddin Nurdin, Guru Profesional \& Implementasi Kurikulum. (Ciputat: PT. Ciputat Press, 2005), h. 15.

${ }^{13}$ Oemar Hamalik, Pendidikan Guru: Berdasarkan Pendekatan Kompetensi, (Jakarta: PT. Bumi Aksara, 2002), h. 1-2.
} 
b. Ada lembaga pendidikan khusus yang menghasilkan pelakunya dengan program dan jenjang pendidikan yang baku serta memiliki standar akademik yang memadai dan yang bertanggung jawab tentang pengembangan ilmu pengetahuan yang melandasi profesi itu.

c. Ada organisasi yang mewadahi para pelakunya untuk mempertahankan dan memperjuangkan eksistensi dan kesejahteraannya.

d. Ada etika dan kode etik yang mengatur perilaku para pelakunya dalam memperlakukan kliennya.

e. Ada sistem imbalan terhadap jasa layanannya yang adil dan baku.

f. Ada pengakuan masyarakat (professional, penguasa dan awan) terhadap pekerjaan itu sebagai suatu profesi. ${ }^{14}$

Penjelasan di atas memperlihatkan bahwa suatu pekerjaan dapat dikatakan profesi jika memilik beberapa ciri tersebut. Karena profesi menuntut sejumlah keahlian dan keterampilan khusus maka penting adanya lembaga yang berperan dalam memberikan pendidikan guna menghasilkan sumber daya manusia yang terampil di berbagai bidang. Untuk memperlihatkan dan menunjukkan kepada masyarakat luas maka suatu profesi pastinya memiliki organisasi yang menaungi keberadaan dari organisasi tersebut dan bertujuan untuk mempertahankan keberadaan dari setiap profesi.

Setiap melakukan suatu pekerjaan tentunya seseorang yang bekerja mendapatkan sejumlah upah atau imbalan. Dalam profesi sendiri imbalan tersebut

\footnotetext{
${ }^{14}$ Syafruddin Nurdin, op. cit., h. 17-18.
}

dilakukan secara adil sesuai dengan proporsi dan tingkatan atau jenis dari masing-masing profesinya itu sendiri. Ketentuan dan aturan dari setiap profesi disesuaikan dengan kode etik dengan tujuan untuk mengontrol kinerja dari setiap profesi.

\section{Guru Sebagai Profesi}

Undang-undang telah menegaskan bahwa guru merupakan suatu jabatan professional, dimana untuk mengemban jabatan tersebut dibutuhkan pelatihan dan kualifikasi yang memadai untuk menjadi persyaratannya. Penguasaan kompetensi dan harus bersertifikasi menunjukkan guru merupakan suatu profesi.

Menurut Mukhtar yang dikutip oleh Barnawi \& Mohammad Arifin, ada tiga alasan mendasar mengapa guru harus menjadi pekerjaan professional, yaitu:

a. Karena guru bertanggung jawab menyiapkna sumber daya manusia (SDM) yang berkualitas, beriman, bertakwa, dan berilmu pengetahuan, serta memahami teknologi;

b. Karena guru bertanggung jawab bagi kelangsungan hidup suatu bangsa. Menyiapkan seorang pelajar untuk menjadi seorang pemimpin masa depan.

c. Karena guru bertanggung jawab atas keberlangsungan budaya dan peradaban suatu generasi.

Selain itu, guru juga memiliki kode etiknya sendiri yang mencirikan pekerjaannya itu adalah profesi. Setiap profesi wajib mempunyai kode etiknya masing-masing. Menurut Rugaiyah \& Atiek Sismiati kode etik suatu profesi adalah "berupa norma-norma yang harus diindahkan oleh setiap anggota profesi di 
dalam melaksanakan tugas profesinya dan dalam hidupnya di masyarakat". ${ }^{15}$ Jadi kode etik pada suatu profesi merupakan suatu pedoman yang berisi aturan maupun norma yang harus diikuti bagi setiap anggota profesi. Dimana aturan tersebut adalah untuk mengatur anggota profesi dalam menjalankan tugas keprofesiannya tersebut. Kode etik dibuat bukan tanpa alasan dan tujuan. Adapun tujuan dari dibuatnya kode etik guna untuk kepentingan bagi anggota profesinya juga.

\section{Guru IPS Profesional}

Sama seperti guru-guru mata pelajaran pada umumnya. Guru IPS merupakan sebagai suatu profesi, yang diharapkan mampu bekerja secara professional sesuai dengan kemampuan dan kualifikasi yang dimiliki. Mengajar sesuai dengan latar belakang pendidikan yaitu yang berkaitan dengan ilmu-ilmu sosial, memiliki penguasaan tentang ilmu pengetahuan sosial secara mendalam serta penguasaan tentang kemampuan dalam mengelola pembelajaran IPS secara lebih menyenangkan. Seperti diketahui bahwa mata pelajaran IPS di sekolah lebih banyak menghafal, jadi diharapkan guru IPS mampu mengemas pembelajaran secara lebih inovatif sehingga tujuan pembelajaran IPS dapat tercapai.

Dalam pandangan Al-Qur'an guru professional adalah "guru yang $\mathrm{Al}$ Qowiyyum dan Al-Amin. Al-Qowiyyum artinya mempunyai kekuatan, mempunyai kemampuan, mempunyai kompetensi. Sedangkan guru yang Al-Amin artinya guru yang dapat dipercaya, yang mempunyai

${ }^{15}$ Rugaiyah dan Atiek Sismiati, Profesi Kependidikan, (Bogor: Ghalia Indonesia, 2011), h. 13. komitmen terhadap profesinya". ${ }^{16}$ Dalam hal ini, guru IPS harus mampu menunjukkan sikap profesionalnya bukan hanya dalam segi keilmuan dan keahlian, tapi kemampuan personal yang ditunjukkan dengan kepribadian yang baik. Karena hakikatnya, guru merupakan pekerjaan yang melibatkan banyak pihak, jadi untuk menunjang pekerjaannya tersebut, guru harus mampu bekerja sama dan mendapat kepercayaan dari orangorang yang ada di sekitar ruang lingkup pekerjaannya.

Sama seperti profesi lainnya, guru yang professional juga dituntut untuk memiliki sejumlah keahlian dan kompetensi sebagai syarat dari pekerjaan profesinya tersebut. Berkaitan dengan kompetensi, Undang-Undang juga mengatur sejumlah kompetensi yang harus dimiliki oleh guru professional. Kompetensi adalah kumpulan pengetahuan, perilaku, dan keterampilan yang harus dimiliki guru untuk mencapai tujuan pembelajaran dan pendidikan. Kompetensi diperoleh melalui pendidikan, pelatihan, dan belajar mandiri dengan memanfaatkan sumber belajar. ${ }^{17}$ Sedangkan dalam Undang-Undang Republik Indonesia nomor 14 Tahun 2005 tentang Guru dan Dosen, dijelaskan bahwa "kompetensi adalah seperangkat pengetahuan, keterampilan, dan perilaku yang harus dimiliki, dihayati, dan dikuasai oleh guru atau dosen dalam melaksanakan

\footnotetext{
${ }^{16}$ Najib Sulhan, Karakter Guru Masa Depan, (Surabaya: Jaring Pena, 2011), h. 56-57.

${ }^{17}$ Jejen Musfah, Peningkatan Kompetensi Guru: Melalui Pelatihan dan Sumber Belajar Teori dan Praktik, (Jakarta: Kencana Prenada Media Group, 2011), h. 27.
} 
tugas keprofesionalan."18 Di sisi lain, kompetensi juga merupakan suatu perwujudan dari kemampuan seseorang dalam memenuhi berbagai syarat yang diperlukan dalam sebuah profesi. Maka dari itu, kompetensi memiliki keterkaitan dengan standarisasi dari setiap profesi yang dijalani. Orientasinya tidak hanya dari keberhasilan seorang guru menjalani profesinya, tetapi juga bagaimana ia berhasil bekerja sama dengan lembaga, di mana dalam hal ini sekolah maupun pemerintah untuk dapat memenuhi dan mencapai tujuan yang diharapkan. Kompetensi yang diharapkan guru agar dapat memenuhinya dicapai melalui sejumlah pendidikan dan berbagai program yang memiliki tujuan untuk terus mengembangkan dan meningkatkan kompetensi guru yang profesional.

Dalam Undang-Undang yang terkait tentang guru dan dosen, disebutkan bahwa ada beberapa kompetensi yang harus dimiliki oleh guru, yaitu kompetensi kepribadian, kompetensi sosial, kompetensi professional, dan terakhir kompetensi pedagogik. Sudah dijelaskan di atas bahwa guru adalah suatu profesi yang menuntut sebuah tanggung jawab, syarat, ketentuan, standarisasi, ataupun kompetensi yang harus dimiliki dalam mewujudkan dan menunjang pekerjaan secara professional.

\section{Pengembangan Berkelanjutan}

Keprofesian

Sebagai suatu profesi yang menuntut sikap professional dengan dasar keilmuan dan kemampuan yang didapat melalui pendidikan, guru juga diharuskan untuk

\footnotetext{
${ }^{18}$ Undang-Undang Nomor 14 Tahun 2005 tentang Guru dan Dosen Bab I pasal 1, h. 3.
}

senantiasa mengikuti perkembangan zaman dan menyesuaikan perubahan yang ada dengan pembelajaran yang akan dilakukan. Untuk itu, guru juga harus senantiasa melakukan pengembangan terhadap profesinya secara berkelanjutan. Hal ini sesuai dengan kewajiban guru dalam menjalankan profesinya sebagai seorang yang professional yang tertera dalam Undang-Undang No. 14 Tahun 2005 tentang Guru dan Dosen Bab IV pasal 20 bagian b yaitu "guru berkewajiban untuk meningkatkan dan mengembangkan kualifikasi akademik dan kompetensi secara berkelanjutan sejalan dengan perkembangan ilmu pengetahuan, teknologi, dan seni."19

Pengembangan

keprofesian berkelanjutan adalah pengembangan kompetensi guru yang dilaksanakan sesuai dengan kebutuhan, secara bertahap, berkelanjutan untuk meingkatkan profesionalitas guru. $^{20}$ Jadi melalui pengembangan profesi berkelanjutan ini guru senantiasa dapat meningkatkan serta mengembangkna kompetensi dan kemampuan yang dimilikinya melalui program-program yang dilaksanakan baik oleh diri sendiri maupun program yang disusun oleh pemerintah. Karena jika dilihat dari bentuk pengembangan profesi berkelanjutan itu bisa dilakukan dari inisiatif gurunya sendiri dalam mengembangkan kompetensinya dengan berbagai cara. Sebaliknya pengembangan professional berkelanjutan dapat juga

${ }^{19}$ Undang-Undang Republik Indonesia Nomor 14 Tahun 2005 tentang Guru dan Dosen Bab IV pasal 20, h. 10.

${ }^{20}$ Pusat Pengembangan Profesi Pendidik, Pedoman Pengelolaan Pengembangan Keprofesian Berkelanjutan, (Jakarta: Kementerian Pendidikan dan Kebudayaan, 2012), h. 5. 
dilakukan secara institusional atas inisiatif dari kepala sekolah, atau otoritas pendidikan terkait, misalnya melalui perkumpulan dalam wadah-wadah guru seperti Kelompok Kerja Guru (KKG), Musyawarah Guru Mata Pelajaran (MGMP), Kelompok Kerja Kepala Sekolah (K3S), Musyawarah Kerja Kepala Sekolah (MKKS). ${ }^{21}$

Tujuan umum pengembangan keprofesian berkelanjutan adalah untuk meningkatkan kualitas layanan pendidikan di sekolah/madrasah dalam rangka meningkatkan mutu pendidikan. ${ }^{22}$ Secara khusus tujuan pengembangan keprofesian berkelanjutan adalah sebagai berikut:

a. Meningkatkan kompetensi guru untuk mencapai standar kompetensi yang ditetapkan dalam peraturan perundangan yang berlaku.

b. Memutakhirkan kompetensi guru untuk memenuhi kebutuhan guru dalam perkembangan ilmu pengetahuan, teknologi dan seni untuk memfasilitasi proses pembelajaran peserta didik.

c. Meningkatkan komitmen guru dalam melaksanakan tugas pokok dan fungsinya sebagai tenaga professional.

d. Menumbuhkan rasa cinta dan bangga sebagai penyanding profesi guru.

e. Meningkatkan citra, harkat, dan martabat profesi guru di masyarakat.

f. Menunjang pengembangan karir guru. $^{23}$

Adapun unsur pengembangan keprofesian berkelanjutan menurut Permenneg PAN dan RB Nomor 16 Tahun 2009 meliputi:

\footnotetext{
${ }^{21}$ Ibid., h. 19-20.

${ }^{22}$ Pusat Pengembangan Profesi Pendidik, op. cit., h. 6.

${ }^{23}$ Ibid., h. 6-7.
}

a. Pengembangan diri, adalah upaya untuk meningkatkan profesionalisme diri agar memiliki kompetensi yang sesuai dengan peraturan perundangundangan atau kebijakan pendidikan nasional serta perkembangan ilmu pengetahuan, teknologi, dan/atau seni. Kegiatan pengembangan diri dapat dilakukan melalui diklat fungsional dan/atau kegiatan kolektid guru yang meningkatkan kompetensi dan/atau keprofesian guru.

b. Publikasi ilmiah, adalah karya tulis ilmiah yang telah dipublikasikan kepada masyarakat sebagai bentuk kontribusi guru etrhadap peningkatan kualitas proses pembelajaran di sekolah dan pengembangan dunia pendidikan.

c. Karya inovatif, adalah karya yang bersifat pengembangan, modifikasi atau penemuan baru sebagai bentuk kontribusi guru terhadap peningkatan kualitas proses pembelajaran di sekolah dan pengembangan dunia pendidikan, sains/teknologi, dan seni. ${ }^{24}$

\section{Bentuk Kegiatan yang Dilakukan oleh Musyawarah Guru Mata Pelajaran (MGMP) IPS MTs Jakarta Timur dalam pengembangan profesi guru berkelanjutan}

MGMP didirikan dengan tujuan sebagai wadah bagi guru untuk bertukar pikiran maupun informasi yang berkaitan dengan proses pembelajaran ataupun masalah-masalah yang terkadang dihadapi di dalam kelas. Di dalam MGMP sendiri yang merupakan tempat berkumpulnya guru-guru yang mengajar satu mata pelajaran yang sama di sekolah yang

${ }^{24}$ Ibid., h. 8-13. 
berbeda-beda memiliki sejumlah aktivitas dan kegiatan yang dirancang guna memberikan manfaat dan diharapkan dapat memecahkan persoalan atau masalah yang dihadapi guru. Selain itu kegiatan-kegiatan yang ada di dalamnya juga bertujuan untuk meningkatkan kompetensi guru yang bersangkutan. Dalam hubungannya dengan pengembangan keprofesian berkelanjutan (PKB) dimana unsur kegiatan pengembangannya terdiri dari kegiatan pengembangan diri, kegiatan publikasi ilmiah, dan kegiatan karya inovatif dapat dilakukan atau diikuti guru dalam kegiatan yang diadakan MGMP.

Sejumlah kegiatan maupun aktivitas yang dilaksanakan dalam MGMP tentunya terlebih dahulu dirancang dan disesuaikan dengan kebutuhan guru atau anggotanya. Dalam pedoman pengembangan MGMP, terdapat beberapa standar dalam pengembangan MGMP, salah satunya yaitu:

\section{Standar Program}

a. Penyusunan program KKG/MGMP dimulai dari menyusun Visi, Misi, Tujuan, sampai kalender kegiatan.

b. Program KKG/MGMP diketahui oleh Ketua KKKS (Kelompok Kerja Kepala Sekolah) atau Ketua MKKS (Musyawarah Kerja Kepala Sekolah) dan disyahkan oleh Kepala Dinas Pendidikan Kabupaten/Kota.

c. Program KKG/MGMP terdiri dari program rutin dan program pengembangan.

d. Program rutin sekurang-kurangnya terdiri dari: Diskusi permasalahan pembelajaran, Penyusunan silabus, program semester, dan Rencana Program Pembelajaran, Analisis kurikulum, Penyusunan instrument evaluasi pembelajaran, Pembahasan materi dan pemantapan menghadapi Ujian Nasional.

e. Program pengembangan dapat dipilih sekurang-kurangnya tiga dari kegiatankegiatan berikut: Penelitian, Penulisan Karya Tulis Ilmiah, Seminar, lokakarya, koloqium (paparan hasil penelitian), dan diskusi panel, Pendidikan dan pelatihan berjenjang (diklat berjenjang), Penerbitan jurnal KKG/MGMP, Penyusunan website KKG/MGMP, Forum KKG/MGMP provinsi, Kompetisi kinerja guru, Peer Coaching (Pelatihan sesama guru menggunakan media ICT), Lesson Study (Kerjasama antarguru untuk memecahkan masalah pembelajaran), Professional Learning Community (komunitas-belajar professional). ${ }^{25}$

Aktivitas atau kegiatan yang diadakan dalam MGMP IPS MTs Jakarta Timur ini sudah memenuhi standar, yaitu adanya kegiatan rutin yang diadakan sebulan sekali, dan ada kegiatan pengembangan. Kegiatan rutin yang diadakan itu disesuaikan dengan kalender akademik. Jiika di awal tahun ajaran baru kegiatan yang diadakan yaitu tentang penyusunan perangkat pembelajaran seperti program tahunan, program semester, RPP, dan silabus. Jika mendekati waktu ujian sekolah baik itu UTS atau UAS maka kegiatan yang diadakan yaitu pembuatan kisi-kisi dan soal ujian. Diluar dari kegiatan tersebut, di sela-sela kegiatan atau di waktu istirahat pengurus dan anggota juga melakukan kegiatan diskusi

${ }^{25}$ Direktorat Profesi Pendidik, Standar Pengembangan: Kelompok Kerja Guru (KKG) Musyawarah Guru Mata pelajaran (MGMP), (Jakarta: Departemen Pendidikan Nasional, 2008), h. 7 . 
dan sharing tentang permasalahan yang dihadapi masing-masing serta bersamasama mencari solusinya. Aktivitas atau kegiatan rutin yang diadakan oleh MGMP IPS MTs Jakarta Timur ini juga sejalan dengan penelitian Agung Fajar Dwi Nugraha pada MGMP lain yaitu adanya kegiatan pertemuan rutin yang diadakan setiap satu bulan sekali dengan pembahasan diskusi permasalahan pembelajaran, pelatihan penyusunan silabus serta RPP, dan penyusunan kisi-kisi soal. $^{26}$

Selanjutnya dalam kegiatan pengembangan keprofesian berkelanjutan (PKB), guru-guru yang aktif dalam MGMP IPS MTs Jakarta Timur ini sudah melakukan pengembangan diri dengan keikutsertaannya dalam setiap kegiatan di MGMP IPS MTs Jakarta Timur, dimana pengembangan diri termasuk salah satu unsur dari pengembangan keprofesian berkelanjutan (PKB). Kemudian dalam hal kegiatan publikasi ilmiah, MGMP IPS MTs Jakarta Timur sejak tahun 2012 sampai sekarang hanya pernah melakukan satu kali kegiatan seminar atau workshop tentang Penelitian Tindakan Kelas (PTK) yang diadakan di Pulau Seribu pada tahun 2015 lalu, jadi untuk unsur kegiatan publikasi ilmiah dinilai masih kurang. Terakhir dalam hal pembuatan karya inovatif, MGMP IPS MTs Jakarta Timur ini juga belum pernah mengadakan kegiatan yang memfasilitasi anggotanya dalam membuat karya inovatif.

\footnotetext{
${ }^{26}$ Agung Fajar Dwi Nugraha, "Upaya Musyawarah Guru Mata Pelajaran (MGMP) Fiqih Kabupaten Sleman dalam Peningkatan Profesionalisme Guru Fiqih Madrasah Tsanawiyah Kabupaten Sleman", Skripsi S1 Pendidikan Agama Islam Fakultas Tarbiyah Universitas Islam Negeri Sunan Kalijaga Yogyakarta, 2009, h. 60-61. Tidak dipublikasikan.
}

Berbicara soal aktivitas yang dilakukan oleh pengurus maupun anggota dalam MGMP IPS MTs Jakarta Timur ini, berkaitan pula dengan peran yang dilakukan pengurus maupun anggota dalam setiap kegiatan. Berdasarkan hasil penelitian, peran pengurus secara umumnya yaitu mengadakan dan mengatur kegiatan yang akan dilaksanakan anggota. Pengurus juga bertanggung jawab atas kegiatan yang dilaksanakan. Untuk peran anggotanya sendiri yaitu dengan menghadiri setiap kegiatan yang diadakan di MGMP IPS MTs Jakarta Timur dan memberikan saran serta pendapatnya terkait dengan kegiatan yang telah dilaksanakan agar lebih baik lagi dari sebelumnya. Selain itu, ada satu orang anggota MGMP IPS MTs Jakarta Timur yang pernah diminta pengurus untuk menjadi persentator dalam kegiatan publikasi ilmiah tentang workshop PTK yang diadakan oleh MGMP IPS MTs Jakarta.

Aktivitas pengembangan keprofesian berkelanjutan yang diadakan oleh MGMP IPS MTs Jakarta Timur juga sejalan dengan penelitian Sujianto, Amat Mukhadis, dan Isnandar yang meneliti tentang kegiatan pengembangan keprofesian (PKB) pada guru yang bersertifikat dan menunjukkan bahwa pengembangan profesionalitas berkelanjutan guru bersertifikat pendidik di SMK rumpun teknologi se-Malang Raya masih tergolong rendah, sebagian besar guru hanya kadang-kadang melakukan investasi pengembangan diri, publikasi ilmiah, dan membuat karya inovatif. ${ }^{27}$

\footnotetext{
${ }^{27}$ Sujianto, dkk, "Pengembangan Profesionalitas Berkelanjutan Guru Bersertifikat
} 
7. Manfaat yang dirasakan oleh guru setelah mengikuti kegiatan Musyawarah Guru Mata Pelajaran (MGMP) IPS MTs Jakarta Timur dalam pengembangan profesi guru berkelanjutan

Berdasarkan hasil penelitian, ada manfaat yang dirasakan oleh anggota setelah mengikuti setiap kegiatan yang diadakan oleh MGMP IPS MTs Jakarta Timur ini. Manfaat tersebut diantaranya tambahan informasi bagi guru yang berkaitan dengan proses pembelajaran, bisa mendapatkan solusi atas permasalahan yang dihadapi guru dalam proses pembelajaran, adanya peningkatan kompetensi yang dirasakan oleh guru. Dimana manfaat yang dirasakan oleh guru bisa diterapkan ke dalam proses pembelajaran dan berpengaruh baik terhadap hasil belajar siswa. Manfaat yang dirasakan tersebut sesuai dengan tujuan yang tertulis dalam Standar Pengembangan Kelompok Kerja Guru (KKG) Musyawarah Guru Mata Pelajaran (MGMP) Direktorat Jenderal Peningkatan Mutu Pendidik dan Tenaga Kependidikan Departemen Pendidikan Nasional Republik Indonesia tahun 2008 menyebutkan beberapa tujuan dari pelaksanaan MGMP, yaitu:

a. Memperluas wawasan dan pengetahuan guru dalam berbagai hal, khususnya penguasaan substansi materi pembelajaran, penyusunan silabus, penyusunan bahan-bahan pembelajaran, strategi pembelajaran, metode pembelajaran, memaksimalkan pemakaian sarana/prasarana belajar, memanfaatkan sumber belajar.

Pendidik di SMK Rumpun Teknologi”, Jurnal Teknologi dan Kejuruan, Vol. 35, 2012, h. 1. b. Memberi kesempatan kepada anggota kelompok kerja atau musyawarah kerja untuk berbagai pengalaman serta saling memberikan bantuan dan umpan balik.

c. Meningkatkan pengetahuan dan keterampilan, serta mengadopsi pendekatan pembaharuan dalam pembelajaran yang lebih professional bagi peserta kelompok kerja atau musyawarah.

d. Memberdayakan dan membantu anggota kelompok kerja dalam melaksanakan tugas-tugas pembelajaran di sekolah.

e. Mengubah budaya kerja anggota kelompok kerja atau musyawarah kerja (meningkatkan pengetahuan, kompetensi dan kinerja) dan mengembangkan profesionalisme guru melalui kegiatan-kegiatan pengembangan professionalism di tingkat KKG/MGMP.

f. Meningkatkan mutu proses pendidikan dan pembelajaran yang tercermin dari peningkatan hasil belajar peserta didik.

g. Meningkatkan kompetensi guru melalui kegiatan-kegiatan di tingkat $\mathrm{KKG} / \mathrm{MGMP}^{28}$

Manfaat yang didapat oleh anggota MGMP IPS MTs Jakarta Timur juga sejalan dengan hasil penelitian Eka Selvi Handayani pada MGMP PKn yang menyebutkan bahwa adanya berbagai manfaat atau kontribusi yang diberikan oleh kegiatan MGMP PKn yaitu:

1) Memberikan sosialisasi kurikulum yang sedang berlaku dan gambaran serta pemahaman tentang silabus yang berlaku agar dalam pelaksanaan kegiatan belajar mengajar dapat menjadi lebih baik.

\footnotetext{
${ }^{28}$ Direktorat Profesi Pendidik, op. cit., h. 4-5.
} 
2) Memberikan pembelakalan dan solusi tentang permasalahan pembelajaran PKn di sekolah-sekolah.

3) Memberikan pembekalan bagi guru mata pelajaran PKn kelas X, XI dan XII dalam menentukan KKM (Kriteria Ketuntasan Minimal).

4) Memberikan pembekalan bagi penyusunan RPP (Rencana Pelaksanaan Pembelajaran) PKn, pembekalan model-model pembelajaran PKn.

5) Pembekalan model-model pembelajaran PKn melalui eksploitasi model pembelajaran $\mathrm{PKn}$ dalam kegiatan MGMP PKn memberikan wawasan yang berharga. ${ }^{29}$

Selain itu, dalam kegiatan pengembangan workshop PTK yang telah diadakan oleh MGMP IPS MTs Jakarta Timur, anggota juga mendapatkan sertifikat yang dapat digunakan untuk kenaikan pangkat.

h. Kendala yang dihadapi dalam kegiatan Musyawarah Guru Mata Pelajaran (MGMP) IPS MTs Jakarta Timur dalam pengembangan profesi guru berkelanjutan

Kendala merupakan hal-hal yang menjadi faktor berjalannya kegiatan yang kurang maksimal. Dalam setiap kegiatan yang diadakan oleh MGMP MTs Jakarta Timur ditemukan beberapa kendala, baik yang dihadapi oleh pengurus maupun anggota. Kendala atau masalah yang dihadapi pastinya harus ada upaya untuk mengatasinya, agar kegiatan yang

${ }^{29}$ Eka Selvi Handayani, "Studi Tentang Kontribusi Musyawarah Guru Mata Pelajaran (MGMP) PKN pada Peningkatan Kualitas Kegiatan Belajar Bidang Studi PKN di SMA Negeri 2 Samarinda", Jurnal Pendas Mahakam, Vol. 1, 2016, h. 17-19. dilaksanakan bisa berjalan sesuai dengan rencana. Berdasarkan hasil penelitian, kendala yang dihadapi oleh pengurus maupun anggota MGMP IPS MTs Jakarta Timur ini diantaranya terbatasnya tempat pelaksanaan kegiatan. Dimana tidak semua sekolah atau Madrasah Negeri yang ada di Jakarta Timur menyediakan tempat untuk pelaksanaan kegiatan. Namun upaya yang dilakukan pengurus untuk mengatasinya yaitu dengan cara menentukan lokasi kegiatan dengan cara bergilir, jadi ada pemerataan tempat dan tidak hanya terfokus pada satu tempat saja. Walaupun ada beberapa sekolah atau madrasah yang tidak memiliki tempat, sekalipun di masjid ataupun perpustakaan sekolah pengurus dan anggota tidak merasa keberatan, karena yang terpenting adalah kegiatan berkumpulnya.

Kendala selanjutnya yaitu tentang jadwal mengajar guru yang berbeda-beda yang tidak memungkinkan seluruh guru IPS yang mengajar di MTs Negeri Jakarta Timur ini memiliki waktu kosong yang sama serta sulitnya izin yang diberikan sekolah untuk guru yang mau menghadiri kegiatan MGMP. Upaya yang dilakukan pengurus yaitu memberikan himbauan kepada bagian kurikulum ataupun Kepala Madrasah agar bisa mengosongkan jadwal guru IPS di hari selasa, dimana hari selasa menjadi hari yang ditetapkan untuk melaksanakan pertemuan setiap satu bulan sekali. Tetapi yang terjadi, masih ada saja guru yang mempunyai jadwal mengajar di hari selasa, akhirnya guru yang bersangkutan tidak dapat menghadiri kegiatan MGMP sehingga tingkat kehadiran dalam kegiatan menjadi rendah. Kendala lain yang menyebabkan rendahnya tingkat kehadiran anggota yaitu 
kurangnya informasi tentang pelaksanaan kegiatan MGMP IPS MTs Jakarta Timur yang merata, jadi masih ada guru yang tidak mendapatkan informasi tentang hal tersebut. Selain itu penyampaian informasi yang telat dan terkesan mendadak dikeluhkan juga oleh guru-guru.

Kendala selanjutnya yaitu akses lokasi kegiatan yang jauh. Jumlah MTs Negeri di Jakarta Timur ini paling banyak daripada wilayah administratif Jakarta yang lain, jadi persebarannya juga cukup luas. Misalnya saja jika lokasi kegiatannya ada di daerah Cakung yang lokasinya hampir dekat dengan daerah Bekasi, maka guru yang ada di daerah Cijantung yang lokasinya dekat dengan daerah Jakarta Selatan merasa itu terlalu jauh untuk dijangkau, begitupun sebaliknya. Walaupun pengurus sudah mengupayakan lokasi kegiatan secara bergilir tetapi kendala semacam ini masih sering ditemukan. Upaya yang dilakukan oleh anggota jika mau menghadiri kegiatan yaitu biasanya dengan berangkat berbarengan dengan rekan guru lain yang memiliki kendaraan pribadi.

Kendala selanjutnya yaitu kurang perhatiannya pemerintah atau orang-orang terkait terhadap keberadaan MGMP IPS MTs Jakarta Timur ini. Dimana semua kegiatan dan aktivitas yang diadakan merupakan hasil kerja dan inisiatif bersama pengurus maupun anggota secara mandiri. Tidak adanya arahan tersebut yang menyebabkan kegiatan yang dilaksanakan cakupannya tidak terlalu luas dan hanya terbatas pada pertemuan rutin saja. Untuk membuat suatu kegiatan seperti seminar atau workshop lainnya itu memerlukan narasumber ahli dan tidak ada dana yang cukup untuk itu. Terkait dengan penjelasan di atas soal kendala, hasil penelitian Ahmad Juanda yang meneliti tentang kendala Musyawarah Guru Mata Pelajaran (MGMP) IPS dalam Mengembangkan Kompetensi Profesional dan Pedagogi Guru IPS SMP di Kabupaten Sleman Tahun 2013/2014 juga menyebutkan adanya beberapa kendala yang sama, yaitu:

1) Kurangnya dukungan dari beberapa bagian kurikulum SMP dan beberapa kepala SMP di Kabupaten Sleman dalam menyesuaikan jadwal maupun memberika izin bagi guru mata pelajaran IPS untuk mengikuti kegiatan MGMP IPS Kabupaten Sleman. Hal ini mengakibatkan beberapa anggota dan pengurus MGMP IPS Kabupaten Sleman tidak bisa hadir dalam kegiatan-kegiatan yang telah dilaksanakan.

2) Kurang sadarnya anggota terhadap pentingnya peran MGMP IPS dalam mengembangkan kompetensi professional dan pedagogi guru IPS.

3) Terbatasnya dana yang dimiliki MGMP IPS SMP Kabupaten Sleman untuk melaksanakan program kerja atau kegiatan pengembangan kompetensi professional dan pedagogi guru IPS. ${ }^{30}$

i. Pendapat dan saran untuk Musyawarah Guru Mata Pelajaran (MGMP) IPS MTs Jakarta Timur dalam pengembangan profesi guru berkelanjutan.

\footnotetext{
${ }^{30}$ Ahmad Juanda, "Kendala Musyawarah Guru Mata Pelajaran (MGMP) IPS dalam Mengembangkan Kompetensi Profesional dan Pedagogi Guru IPS SMP di Kabupaten Sleman Tahun 2013/2014", Skripsi pada Universitas Negeri Yogyakarta, Yogyakarta, 2015, h. 52-53, tidak dipublikasikan.
} 
Berdasarkan hasil penelitian di atas yang menjelaskan tentang adanya kendala yang dihadapi oleh pengurus maupun anggota MGMP IPS MTs Jakarta Timur maka diperlukan keterlibatan anggota untuk memberikan saran dan masukan yang membangun terhadap kinerja pengurus dan kegiatan yang telah dilaksanakan oleh MGMP IPS MTs Jakarta Timur selama ini. Untuk kegiatan rutin, sebagian besar anggota berpendapat bahwa kegiatan yang telah diadakan oleh MGMP IPS MTs Jakarta Timur ini pelaksanaannya sudah cukup baik. Karena MGMP IPS MTs Jakarta Timur ini dinilai yang paling aktif dan eksis dibandingkan dengan MGMP IPS MTs di wilayah administratif Jakarta yang lain. Hal ini dikarenakan jumlah MTs Negeri di wilayah Jakarta Timur ini merupakan yang paling banyak. Tetapi untuk kegiatan yang berkaitan dengan pengembangan keprofesian berkelanjutan (PKB) masih perlu ditingkatkan. Hal ini dikarenakan anggota merasa perlu adanya kegiatan seperti pelatihan dan seminar-seminar untuk meningkatkan kompetensinya. Selanjutnya perlunya ada perhatian dan dukungan dari pemerintah maupun pihak-pihak terkait lainnya dalam menunjang kegiatan pengembangan. Hal ini dimaksudkan karena selama ini MGMP IPS Jakarta Timur tidak bisa mengadakan kegiatan yang cakupannya lebih luas seperti kegiatan pengembangan dikarenakan keterbatasan dana dan terbatasnya biaya.

Dalam hal kepengurusan, anggota menilai kinerja pengurus sudah cukup baik karena sudah memfasilitasi anggotanya dengan kegiatan-kegiatan yang bermanfaat. Hanya saja keaktifan pengurus lebih ditingkatkan lagi dengan mengikutsertakan guru-guru swasta untuk ikut bergabung dalam MGMP IPS MTs Jakarta Timur ini, sehingga tingkat kehadiran anggota menjadi lebih baik lagi dari yang sekarang.

\section{E. Kesimpulan}

Berdasarkan pembahasan yang telah diuraikan sebelumnya, maka dapat disimpulkan sebagai berikut:

1. Bentuk kegiatan yang ada di dalam MGMP IPS MTs Jakarta Timur umumnya terdiri dari dua jenis kegiatan, yaitu program rutin dan program pengembangan. Program rutinnya yaitu penyusunan perangkat pembelajaran seperti program tahunan, program semester, RPP, silabus. Menjelang jadwal ujian sekolah ada kegiatan penyusunan kisi-kisi dan soal ujian. Di sela-sela kegiatan yang sudah terjadwal, guru-guru yang bersangkutan juga sering melakukan diskusi dan sharing seputar permasalahan yang dihadapi dalam proses pembelajaran. Program pengembangannya hanya pernah dilaksanakan satu kali sejak tahun 2012 sampai dengan sekarang, yaitu kegiatan workshop PTK di Pulau Seribu pada tahun 2015.

2. Manfaat yang dirasakan oleh guru setelah mengikuti kegiatan MGMP IPS MTs Jakarta Timur yaitu adanya penambahan informasi, penambahan kompetensi, solusi atas permasalahan yang dihadapi, dan sertifikat yang didapatkan saat mengikuti workshop PTK dapat digunakan untuk kenaikan pangkat. Selain itu manfaat yang didapatkan kemudian diterapkan dalam proses pembelajaran sehingga 
berpengaruh baik terhadap hasil belajar peserta didik.

3. Kendala yang dihadapi dalam kegiatan MGMP IPS MTs Jakarta Timur dalam pengembangan profesi guru berkelanjutan yaitu dihadapi oleh pengurus dan juga anggota. Diantaranya terbatasnya tempat pelaksanaan kegiatan, jadwal mengajar guru yang tidak sesuai dengan jadwal pertemuan MGMP dan sulitnya izin dari sekolah yang bersangkutan mengakibatkan guru tidak bisa hadir dalam kegiatan, penyampaian informasi yang telat dan terkesan dadakan juga menjadi faktor rendahnya kehadiran anggota, akses lokasi kegiatan yang jauh, dan yang terakhir kurangnya perhatian dari pemerintah atau orang-orang terkait membuat MGMP IPS MTs Jakarta Timur ini bergerak secara mandiri dan tidak mampu membuat kegiatan yang cakupan lebih luas karena keterbatasan dana juga. Upaya dalam mengatasi kendala tersebut juga dilakukan oleh pengurus dan anggota yaitu menggilir setiap sekolah untuk menjadi tuan rumah dalam pelaksanaan kegiatan, menghimbau kepada bagian kurikulum atau Kepala Madrasah untuk mengosongkan jadwal guru IPS di hari selasa dan mengizinkan guru-guru IPS untuk mengikuti kegiatan MGMP, untuk menghadiri kegiatan yang aksesnya jauh guru yang memiliki kendaraan pribadi mengajak rekan guru yang lain untuk berangkat bersama.

4. Pendapat dan saran yang diberikan anggota terkait kegiatan yang sudah berjalan dan kinerja pengurus MGMP IPS MTs Jakarta Timur selama ini yaitu sudah dinilai cukup baik dan sarannya pengurus harus lebih proaktif lagi dengan mengajak rekan guru di swasta untuk ikut bergabung sehingga tingkat kehadiran dalam setiap kegiatan meningkat. Selanjutnya untuk kegiatan pengembangan masih harus ditingkatkan lagi dan tidak hanya terfokus pada kegiatan rutinnya saja. Pihak pemerintah dan orang-orang terkaitnya diharapkan mampu melihat dan mendukung keberadaan MGMP IPS MTs Jakarta Timur sebagai wadah yang bisa memfasilitasi guru untuk dapat meningkatkan kompetensinya sebagai guru yang professional sehingga kualitas pendidikan yang didapatkan peserta didik menjadi lebih baik.

\section{DAFTAR PUSTAKA}

Direktorat Profesi Pendidik. Standar Pengembangan: Kelompok Kerja Guru (KKG) Musyawarah Guru Mata Pelajaran (MGMP). Jakarta: Departemen Pendidikan Nasional, 2008.

Hamalik, Oemar. Pendidikan Guru: Berdasarkan Pendekatan Kompetensi. Jakarta: PT Bumi Aksara, 2002.

Handayani, Eka Selvi. Studi Tentang Kontribusi Musyawarah Guru Mata Pelajaran (MGMP) PKN pada Peningkatan Kualitas Kegiatan Belajar Bidang Studi PKN di SMA Negeri 2 Samarinda, Jurnal Pendas Mahakam. Vol. 1, 2016.

Juanda, Ahmad. "Kendala Musyawarah Guru Mata Pelajaran (MGMP) IPS 
dalam Mengembangkan Kompetensi Profesional dan Pedagogi Guru IPS SMP di Kabupaten Sleman Tahun 2013/2014". Skripsi pada Universitas Negeri Yogyakarta: 2015. tidak dipublikasikan.

Moleong, Lexy J. Metode Penelitian Kualitatif. Bandung: PT Remaja Rosdakarya, 2009.

Musfah, Jejen. Peningkatan Kompetensi Guru: Melalui Pelatihan dan Sumber Belajar Teori dan Praktik. Jakarta: Kencana Prenada Media Group, 2011.

Nugraha, Agung Fajar Dwi. "Upaya Musyawarah Guru Mata Pelajaran (MGMP) Fiqih Kabupaten Sleman dalam Peningkatan Profesionalisme Guru Fiqih Madrasah Tsanawiyah Kabupaten Sleman". Skripsi pada Universitas Islam Negeri Sunan Kalijaga Yogyakarta: 2009. tidak dipublikasikan.

Nurdin, Syafruddin. Guru Profesional \& Implementasi Kurikulum. Ciputat: PT. Ciputat Press, 2005.

Pusat Pengembangan Profesi Pendidik. Pedoman Pengelolaan Pengembangan Keprofesian Berkelanjutan. Jakarta: Kementerian Pendidikan dan Kebudayaan, 2012.

Ramayulis. Profesi \& Etika Keguruan. Jakarta: Kalam Mulia, 2013.
Rugaiyah dan Atiek Sismiati. Profesi Kependidikan. Bogor: Ghalia Indonesia, 2011.

Sapriya. dkk. Pembelajaran dan Evaluasi Hasil Belajar IPS. Bandung: UPI Press, 2006.

Sugiyono. Memahami Penelitian Kualitatif. Bandung: Alfabeta, 2014.

-----. Metode Penelitian Kombinasi: Mixed Methods. Bandung: Alfabeta, 2014

Sulhan, Najib. Karakter Guru Masa Depan: Sukses \& Bermartabat. Surabaya: Jaring Pena, 2011.

Sujianto, dkk. Pengembangan Profesionalitas Berkelanjutan Guru Bersertifikat Pendidik di SMK Rumpun Teknologi, Jurnal Teknologi dan Kejuruan. Vol. 35, 2012.

Trianto. Model Pembelajaran Terpadu: Konsep, Strategi, dan Implementasinya dalam Kurikulum Tingkat Satuan Pendidikan (KTSP). Jakarta: PT Bumi Aksara, 2010.

Usman, Husaini dan Purnomo Setiady Akbar. Metodologi Penelitian Sosial. Jakarta: Bumi Aksara, 2008.

UU No. 14 Tahun 2005 tentang Guru dan Dosen. 